\title{
PLGA-Collagen Composite Synthesis with the Antibacterial Addition of Jatropha curcas L. Leaf Extract as Absorbable Surgical Suture Candidate
}

\author{
Karina Dwi Saraswati ${ }^{1}$, Prihartini Widiyanti ${ }^{2 *}$, Dwi Gustiono ${ }^{3}$, Jan Setiawan ${ }^{4}$ \\ ${ }^{1}$ Biomedical Engineering Study Program, Faculty of Science and Technology, \\ Universitas Airlangga, Indonesia \\ ${ }^{2}$ Institute of Tropical Disease, Universitas Airlangga, Indonesia \\ ${ }^{3}$ Pusat Teknologi Material - BPPT, Serpong, Indonesia \\ ${ }^{4}$ Pusat Teknologi Bahan Bakar Nuklir- BATAN \\ *Corresponding author: pwidiyanti@fst.unair.ac.id
}

Keywords: surgical suture, absorbable, PLGA, Jatropha curcas L. leaf extracts

\begin{abstract}
The prevalence rate of surgical wound infections caused by bacteria is an average of 9\% of the 1.4 million patients worldwide. For this reason, a modification of an absorbable surgical suture coated with extract of Jatropha curcas L. leaves to kill and inhibit the growth of microorganisms needs to be made. The forming of multifilament fibers is done by electrospinning method. The test results of the functional groups showed the presence of interaction between PLGA-Collagen with the extract of Jatropha Curcas L. leaves indicated by an absorption band at $2924 \mathrm{~cm}^{-1}$ which showed the vibrations of C-H. The tensile test results showed that all samples were in the range of 19.5-87.1 MPa values which corresponded with the modulus of elasticity of the suture thread in the forehead and elbows. The MTT Assay results showed that the percentage of living cells of all samples was above $50 \%$. The bacterial activity test showed that the inhibition zone were in the range of $5-10 \mathrm{~mm}$. The optimal sample showed the degradation rate of $82.2 \%$ on the 60th day of the soaking period. It can be concluded that PLGA-collagen Jatropha curcas L. extracts is safe composite and has potential as antibacterial absorbable surgical sutures.
\end{abstract}

\section{Introduction}

A wound is anatomical damage to the structure and function of normal skin due to pathological processes originated internally and externally and is susceptible to a particular organ. A wound is damage to skin continuity, mucous membranes, and bones or other body organs. When injuries arise, several effects will appear such as the loss of all or part of organ function, sympathetic stress response, bleeding and blood clots, bacterial contamination, and cell death [1]. Suturing wounds is one of the most important actions in accelerating the wound healing process which aims to reduce the occurrence of bleeding, infection, and prevent the forming of wide scar tissue by tightening back the disconnected tissues.

The numbers of accidents in Indonesia that reach 117 million per year required sutures as reported by the 2013 Central Bureau of Statistics. WHO data showed that for more than a century, surgical care has been an essential component of health care around the world. It is estimated that there are 230 million surgical procedures performed worldwide each year [2]. Scientists have developed surgical suture manufacturing which can be absorbed by the body (absorbable) after the healing process is completed [3]. The absorbable surgical suture has a smaller risk of the reaction of body rejection, has strong characteristics, flexible and able to degrade quickly in the body. There is also no need for the removal of the surgical suture after the wound healing process is over in order to shorten the time and cost [4].

It is thus necessary to make a modification to improve the quality of surgical suture, i.e. the ability to degrade timely, not causing tissue response, having good mechanical strength and its ability to inhibit the growth of bacteria. Poly (lactide-co-glycolic acid) (PLGA) surgical suture has 
shown excellent performance like stitches in the wound healing which is useful as polymer substrate to bring together biological material or chemical drugs to be applied to the tissues and have good mechanical strength properties. With a tensile modulus value as well as its long degradation, the tensile strength of the PLGA surgical suture is reduced to $28 \%$ to $28 \%$ of $100 \%$ of the initial time for four weeks [5]. Collagen is then added because it has several advantages, some of which are its availability in large quantities, that it is easily obtained from living organisms, its ability to inhibit the absorption of toxins and the growth of pathogenic bacteria, its role in cell survival, and its ability to proliferate and help the healing of bone or blood damage [6].

The blend of the two materials is not enough to improve the quality of absorbable surgical suture. In this study, an additional antibacterial material, that is, Jatropha curcas L. is required to kill and inhibit the growth of microorganisms which can slow down the process of wound healing. Jatropha (Jatropha curcas L.) contains secondary metabolite compounds which serve as an antibacterial; the castor leaves and beans contain phenols, terpenoids, flavonoids, saponins [7] and alkaloid [8].

To confirm the quality of the resulting material, some characterizations were performed: the functional group test using the Fourier Transform Infrared (FTIR) to confirm the synthesized material, the tensile strength test to determine the strength of the material when given a certain load, cytotoxicity test with MTT assay method to determine the level of toxicity of the material when implanted into the body. The degradation test using the Phosphate Buffer Saline (PBS) was performed to determine the rate of material degradation in simulated body fluid. The antibacterial test with clear zone method using Staphylococcus aureus was conducted to determine the resistance of gram-positive bacteria against the candidate material of the absorbable surgical sutures.

\section{Materials and Methods}

\section{Materials}

The materials used in this study was PLGA (Poly (lactide-co-glycolic acid)) derived from Polysitech products with a lactide: glycolide ratio of 90: 10 and a molecular weight of 66000$107000 \mathrm{~g} / \mathrm{mol}$. Collagen from cow bone (BATAN Pasar Jumat, South Jakarta). Jatropha curcas L. leaf extracts from Sidoarjo and synthesized with ethanol at the Faculty of Pharmacy, Airlangga University. Chloroform and DMF used as a solvent was a pro analysis material (Merck).

\section{Methods}

Synthesis

Preparations for the samples were conducted by dissolving $(20 \%(\mathrm{w} / \mathrm{v}))$ PGA into the chloroform and DMF. The PLGA was dissolved until homogeneous with a magnetic stirrer for \pm 2 hours. A total of 0.04 grams of collagen type 1 was added to the PLGA solution; and then stirring was performed for \pm 1 hour to dissolve the collagen. Preparation of Jatropha curcas L. leaf extracts: PLGA-collagen was conducted by adding the appropriate concentration variations. The solvent was stirred with a magnetic stirrer until homogeneous. Electrospinning method was used in the making of absorbable surgical suture candidates. A voltage of $\pm 17.3 \mathrm{kV}$ was used to obtain good fiber results. The syringe used was made of a $5 \mathrm{ml}$ sized glass filled with sample solution at a rate of $1 \mathrm{ml} /$ hour.

\section{Fourier Transform Infra Red (FTIR) Test}

FTIR is the testing to analyse functional group of the materials and the possibility of new bond formation. The sample was taken in a small intake and added with $\mathrm{KBr}$ powder as background. The sample was then compacted with hydraulic pump and placed on specimen holder to be irradiated with infrared. The obtained result was absorbance region graphic of wavenumber (cm-1) towards transmittance percentage (\%) [9]. 


\section{Tensile Test}

Determination of the mechanical properties is done by cutting rectangular sample by measuring the length and width of the specimen and the specimen thickness gauge with the micrometer screw. Membrane attributed the tip on a test and the burden of towing unit mounted on the burden of newton. Sample drawn with certain speed until breaking up [10].

\section{Cytotoxicity Test}

Cytotoxicity test was done in MTT Assay method. The steps were done as follows : 1.Preparation of fibroblasts cell culture in laminar flow. We used monolayer BHK-21 cell culture in medium Eagle and FBS $5 \%$ which were planted in roux bottle. This bottle were given treatment in incubator in $37^{\circ} \mathrm{C}$ for 48 hours. The nest step were the incubation of cell culture for 48 hours and then washed with PBS for 5 times to discard serum. The addition of trypsin versene was done to release cells from the wall of bottle and to separate binding between cells in order not to clump together. Cells with density of $2 \times 10^{5}$ put in $100 \mu \mathrm{L}$ medium ( Eagle medium $86 \%$, 1\% penicillin streptomycin and fungizone $100 \mathrm{unit} / \mathrm{ml}$ ), then moved into 96-microwell plate.Each sample were sterilized to the UV rays for more than one night, dissolving 0.05 grams in $1 \mathrm{ml}$ etanol. Sample solution then put in 96-microwell plate as many as $50 \mu \mathrm{L}$, and was incubated for 24 hours in temperature $37^{\circ} \mathrm{C} .5 \mathrm{mg} / \mathrm{mL}$ reagent MTT which has been dissolved in PBS then has been added to each well, incubated for 4 hours in temperature $37^{\circ} \mathrm{C}$. $50 \mu \mathrm{L}$ DMSO reagent has been added to each well then it has been centrifuged $30 \mathrm{rpm}$ for 5 minutes. Then the optical density were measured using Elisa Reader and the percentage of living cells was calculated using equation (1).

$$
\text { Procentage of Living Cell }(\%)=\frac{\text { OD Treatment }- \text { OD Media Control }}{\text { OD Cell Control }- \text { OD Media Control }}
$$

(Equation 1)

Value of cell control optical density wherein :

Treatment $\mathrm{OD}=$ value of sample optical density after treatment

Cell Control OD = value of cell control optical density

Media Control OD = value of media control optical density

Living Cell $\%=$ percentage of cell numbers after treatment [11]

\section{Antibacterial Test}

The bacteria activities test is conducted to know sample resistancy to pathogen bacteria. Method which has been used is diffusion method, using pathogenic bacteria E.coli and S.aureus. Activity indicators of organisms to tested material were characterized by the appearance of clear zone around tested material. lingi. The characteristic susceptible or resistant could be determined by comparing the diameters of zone clear with standard. Culture bacteria S.aureus 1 ose is suspended into $9 \mathrm{ml}$ Trypticase Soy Broth and is homogenized and bred in an incubator $60^{\circ} \mathrm{C} \mathrm{c}$ for 24 hours. Agar nutrient $2 \%(\mathrm{w} / \mathrm{v})$ were prepared as media and nutrients for bacteria.As many as $100 \mu 11$ suspension S. aureus were put in a petri dish sterile $12 \mathrm{~cm}$ and $20 \mathrm{ml}$ agar nutrients is poured into it then placed in room temperature for 30 minutes. Bacteria culture was made in 5 petri dishs with the detail 1 for control sample and 4 for sample with variation of Jatropha curcas $L$ extract. After incubated for 24 hours, then the inhibition zone were observed. The resistancy strength of sample to bacteria were evaluated by comparing clear zone diameter via calculation of difference of inhibition bacteria zone diameter with sample diameter [12].

\section{Degradation Test}

Material used for degradation test is Phosphate Buffered Saline (PBS) with the ph 7,4. Parameters of degradation were declination of weight molecule, crack, colour alternation and mechanical strength. To make a solution of PBS, we used 8 grams of $\mathrm{NaCl}, 0.2$ grams $\mathrm{KCl}$, 1,44 grams $\mathrm{Na}_{2} \mathrm{HPO}_{4}$ and 0.24 grams $\mathrm{KH}_{2} \mathrm{PO}_{4}$ were being dissolved in $800 \mathrm{ml}$ of distillated water. $\mathrm{pH}$ values was set until it reaches 7.4 by using $\mathrm{HCl}$.Sample were soaked in PBS solution for 8 weeks while be noticed and noted all the changes occurred [5]. 


\section{Result and Discussion}

\section{Fourier Transform Infra Red (FTIR) Test Result}

In this study, several samples having PLGA-collagen compositions with the addition of Jatropha curcas L. leaf extract variations were made, namely Sample A (1:0), Sample B (1:0.35), Sample C (1:0.47), Sample D (1:0.56), Sample E (1:0.7). The data of FTIR could be seen in Table 1.

Table 1. Absorption Spectrum Data

\begin{tabular}{|c|c|c|c|c|c|c|c|c|c|c|}
\hline \multirow[b]{2}{*}{ Sample } & \multicolumn{10}{|c|}{ Wave Figures $\left(\mathrm{cm}^{-1}\right)$} \\
\hline & $\begin{array}{l}\mathrm{N}- \\
\mathrm{H}\end{array}$ & Amina & $\begin{array}{c}\text { Aliphatic } \\
\text { groups } \\
\text { (-CH }_{2} \\
\text { dan - } \\
\left.\mathrm{CH}_{3}\right) \\
\end{array}$ & $\begin{array}{c}\mathrm{C}=\mathbf{O} \\
\text { (stretching) }\end{array}$ & $\begin{array}{c}\text { Carbonyl } \\
\text { Group } \\
(\mathbf{C}=\mathbf{O})\end{array}$ & $\mathrm{CH}_{2}$ & $\begin{array}{c}\text { C-O } \\
\text { (stretching) }\end{array}$ & $\begin{array}{l}\text { C- } \\
\text { O }\end{array}$ & $\begin{array}{c}\text { Hydroxyl } \\
\text { Group } \\
\text { (C-O) }\end{array}$ & $\begin{array}{c}\text { C-H } \\
\text { (stretching) }\end{array}$ \\
\hline $\mathbf{A}$ & & - & 1452,30 & \multicolumn{2}{|c|}{1748,37} & - & 1181,65 & & 1082,51 & - \\
\hline B & & - & 1452,83 & \multicolumn{2}{|c|}{1751,08} & 2925,02 & 1182,09 & & 1084,91 & 1381,51 \\
\hline C & & - & 1453,73 & \multirow{2}{*}{\multicolumn{2}{|c|}{$\frac{1753,92}{1752,32}$}} & 2924,72 & 1182,65 & & 1085,59 & 1381,74 \\
\hline D & & - & 1451,78 & & & 2924,02 & 1182,21 & & 1082,04 & 1381,81 \\
\hline $\mathbf{E}$ & & 32,18 & 1451,78 & \multicolumn{2}{|c|}{$\begin{array}{l}\frac{1752,32}{1752,07} \\
\end{array}$} & - & 1182,25 & & 1080,50 & 1358,85 \\
\hline
\end{tabular}

Based on the functional group test results of the five samples which had been discussed one by one, the physical interactions that occur between Poly(lactic-co-glycolic-acid) (PLGA) molecules and collagen molecules were dominant. According to Lee et al [5], the emergence of the functional group $(\mathrm{C}-\mathrm{O})$ stretches is derived from the combination of the compounds contained in the PLGA and collagen. The existence of the PLGA-collagen interactions with the Jatropha curcas $L$. leaf extracts were indicated by the absorption bands of the wavelength range from 1249.82 $2933.33 \mathrm{~cm}^{-1}$ showing the $\mathrm{C}-\mathrm{H}$ stretching vibrations in the aliphatic $\mathrm{C}-\mathrm{H}$ groups. While the functional group test results were in the range of $2924 \mathrm{~cm}^{-1}$ which is the hallmark of the flavonoids in the Jatropha curcas L. leaf extracts.

\section{Tensile Test Result}

The tensile strength test or determining the mechanical properties was carried out by using Instron as we could be seen in Figure 1. The result showed that the value of the five samples meet the standard value of the elastic modulus for the application of surgical sutures on the forehead and elbows based [7], with a value range of elastic modulus of $19.5-87.1 \mathrm{MPa}$. The decline in the value of the modulus of elasticity in samples $C, D$, and $E$ was due to the increasing number of compositions of the Jatropha curcas L. leaf extracts containing ricinoleic acid and phenol as plasticizers, which tended to lower the hydrogen bond and reduced the intermolecular interactions in the polymer [13].

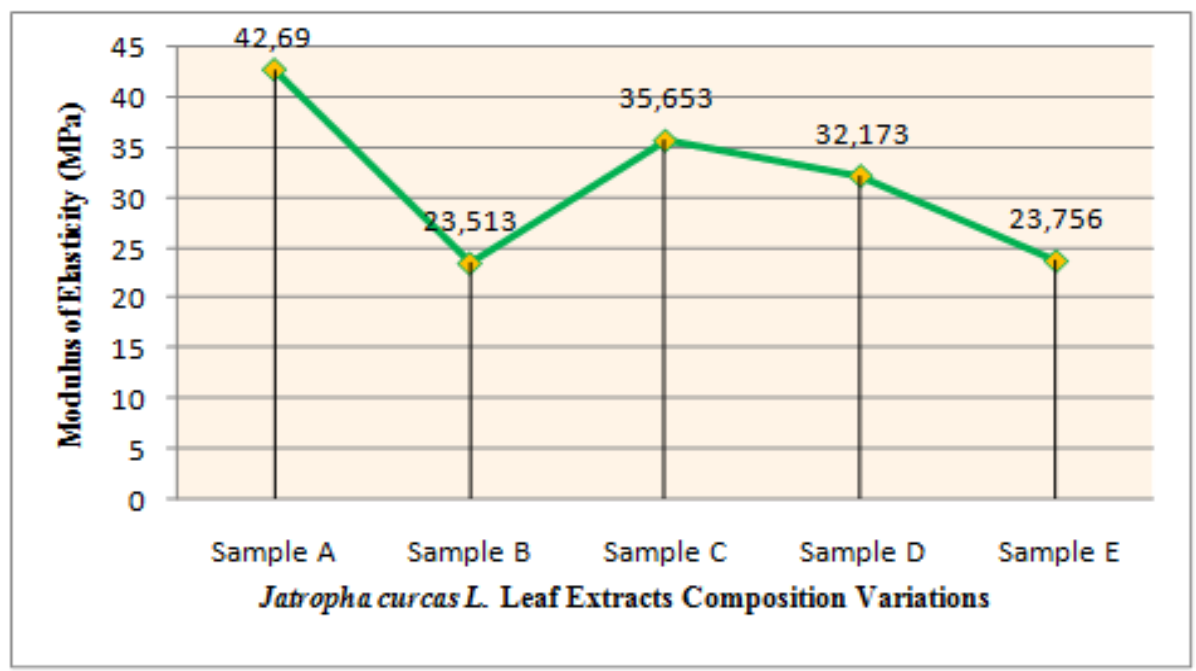

Figure 1. Tensile Strength Test Result Graph 


\section{Cytotoxicity Test Result}

The MTT Assay method was used to test the toxicity level of material. Firstly, the samples were incubated in BHK-21 cells the eagle's medium for 24 hours with MTT to determine the percentage of their life cells and to determine the absorbance wavelengths by using ELISA Reader. The cytotoxicity testing results of the five samples of the absorbable surgical suture candidate showed a value above the toxicity standard of a sample. The percentage of the living cells of the five samples using the Jatropha curcas $L$. leaf extracts showed a value above $50 \%$ with the living cells percentage ranging from $56.66-93.07 \%$ (Figure 2). This value was in accordance with the expectation since a sample is said to be non-toxic when the percentage of the living cells is above $50 \%$ [11]. The results showed that the four samples of the absorbable surgical suture candidate using the Jatropha curcas $L$. leaf extracts are safe and nontoxic for use as surgical sutures.

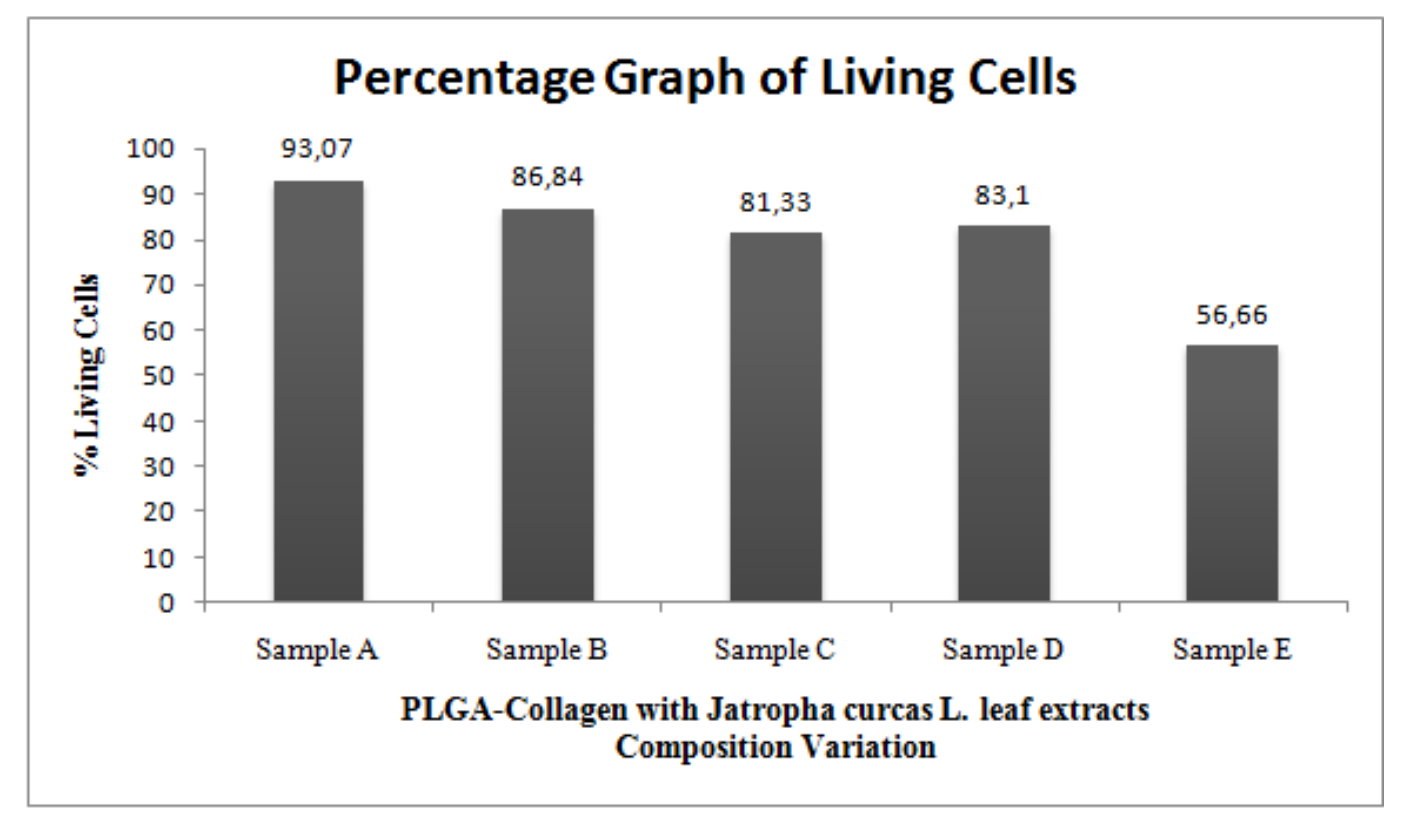

Figure 2. Cytotoxicity Test result Chart

\section{Antibacterial Test Results}

Antibacterial testing was performed using Escherichia coli (negative gram) and Staphylococcus aureus (positive gram) with the agar diffusion method and was repeated four times on the respective variety. Both of these bacterial pathogens were used because they were most frequently related to human activities. The antibacterial activity of Jatropha curcas L.extracts was known from the flavonoids and phenolic compounds (Figure 3,4,5). These two compounds were recognized as antibacterial agents that inhibit the growth of Staphylococcus aureus [14].

Determination of the antibacterial effectiveness was carried out based on the diameter of the inhibition zone formed around the samples in the petri disk for two days. Based on the test results, it is known that the PLGA-collagen samples with the additional of Jatropha curcas L. leaf extract variation are included in the moderate antibiotic power category (inhibitory area 5-10 $\mathrm{mm}$ ). Furthermore, Jatropha curcas L. antibacterial action was categorized in the antibacterial mechanism that damaged the structure of the bacterial cell wall, which served to maintain the microorganism form and restrain bacterial cells by obstructing the cell wall formation so it would induce lysis on the cells. This was in accordance with the research conducted by Namuli [15]. 

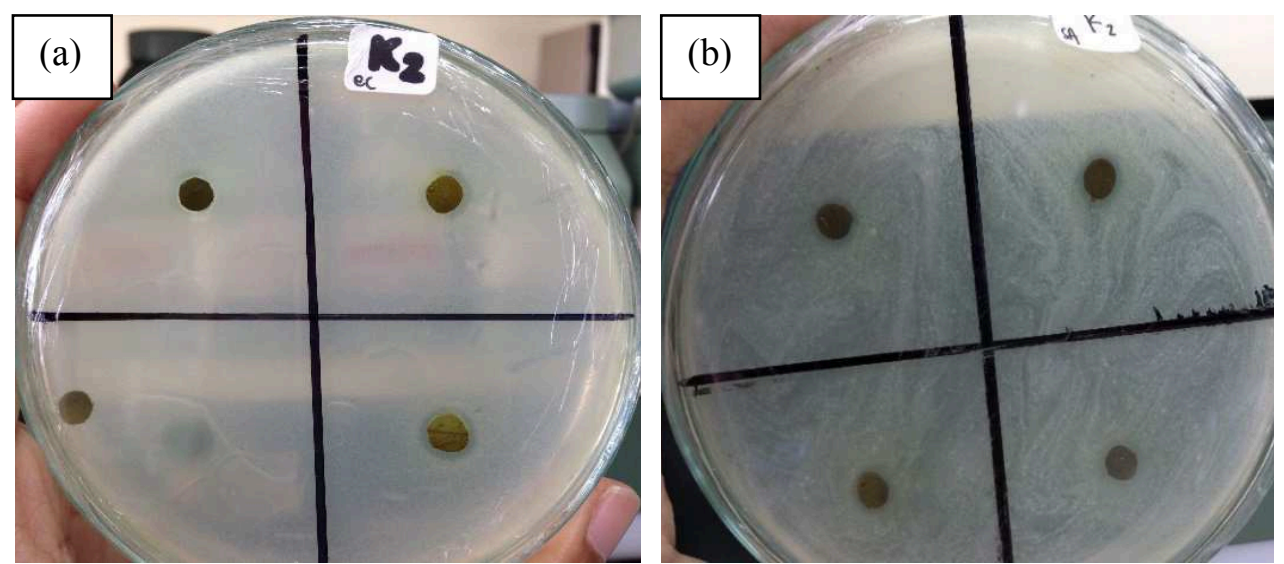

Figure 3. Inhibition Power Test of absorbable surgical suture candidate against (a) Escherichia coli dan (b) Staphylococcus aureus bacteria

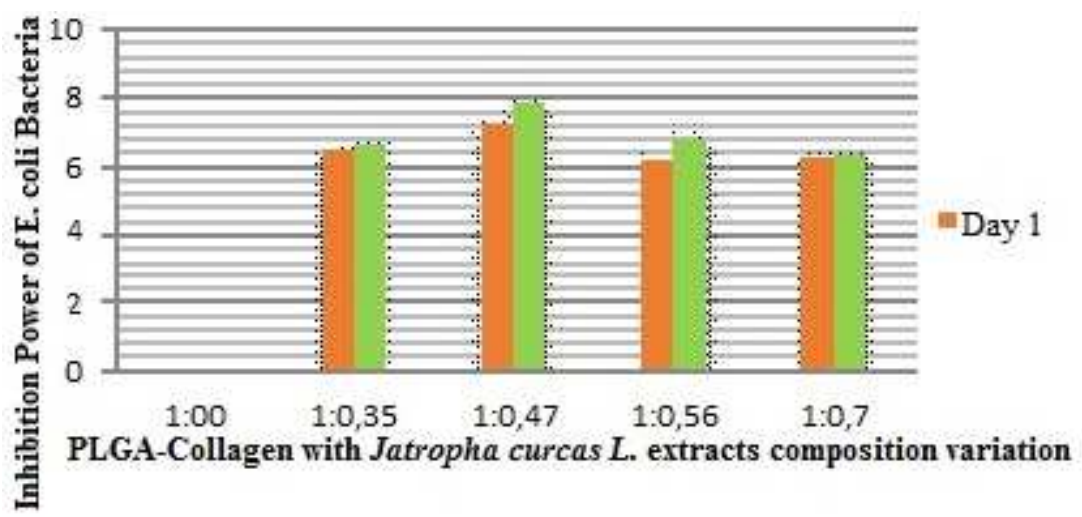

Figure 4. Inhibition Power Test of absorbable surgical suture candidate against Escherichia coli bacteria

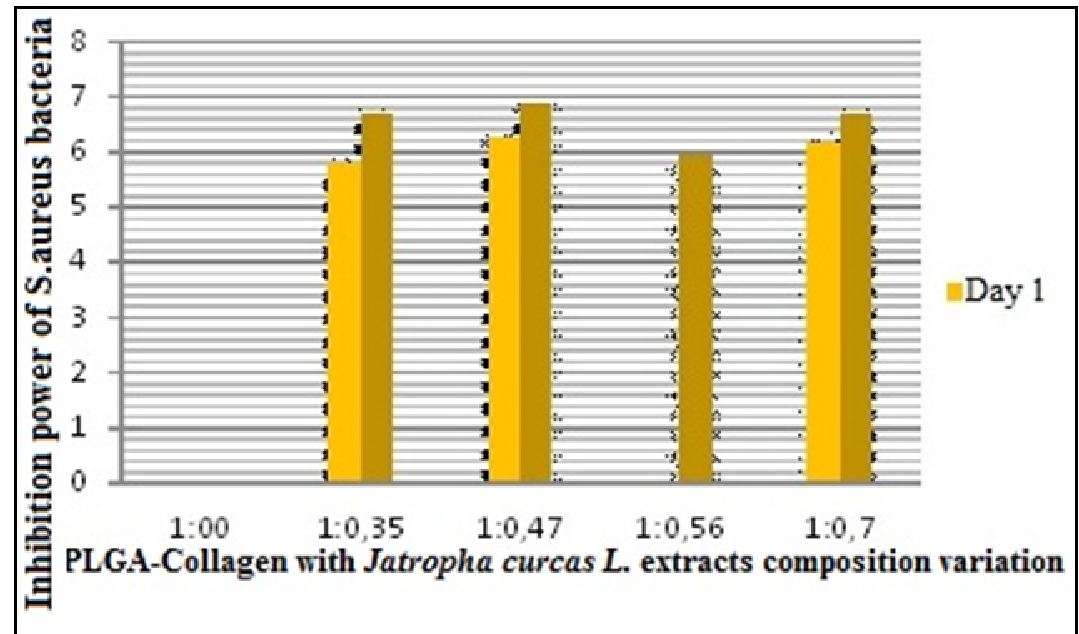

Figure 5. Inhibition Power Test of absorbable surgical suture candidate against Staphylococcus aureus bacteria

\section{Degradation Test Result}

The degradation test was carried out using the Phosphate Buffer Saline (PBS) as body fluid simulation. If the inflammation of the wound disappears, the surgical suture is no longer needed, so the skin itself is able to withstand $80 \%$ of the strain from the normal strength in 60 days after the injury [10]. Based on the test, the five samples showed a degradation mass rate of $89 \%$ after 60 days of soaking time. 


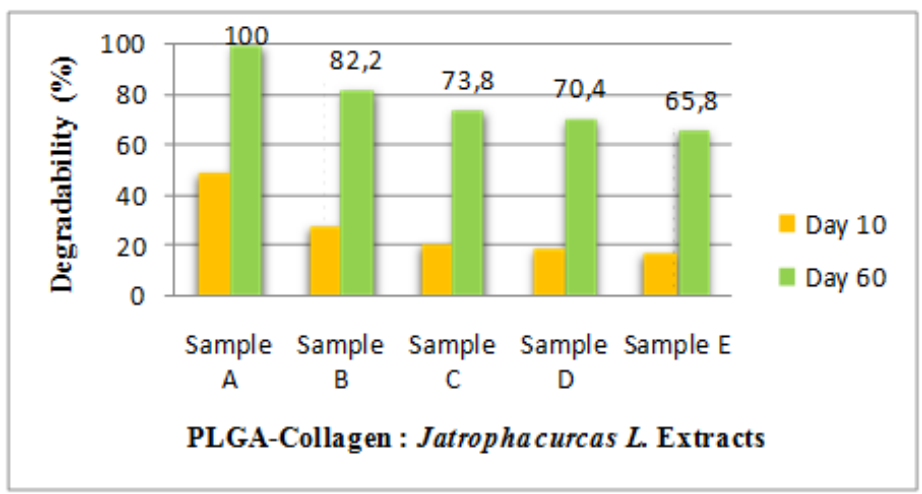

Figure 6. Degradation Test Results Bar Chart

The decline of this degradation rate was affected by the addition of the Jatropha curcas L. leaf extract composition containing phenolic compounds. Phenol compound is soluble in water and in the form of crystalline. Higher crystalline and higher crystal size will slow down the degradation process. Crystal form material is more difficult to degrade compared to the amorphous material due to stronger water penetration capabilities owned by the amorphous material [16].

\section{Conclusion}

The combination of PLGA-collagen with Jatropha curcas L. leaf extracts antibacterial actions is potential as absorbable and antibacterial surgical suture candidate based on the conducted test results, namely the functional group, tensile strength, cytotoxicity, antibacterial and degradation tests.

\section{Acknowledgements}

We would like to express our gratitude to the Center for Nuclear Fuel Technology BATAN for the support in this research.

\section{References}

[1] Potter, P.A., dan Perry, A.G. 2005b. Buku Ajar Fundamental Keperawatan: Konsep, Proses, dan Praktik. Vol. 2. Edisi 4. Alih Bahasa oleh Renata Komalasari et al. Jakarta: EGC.

[2] Kusumayanti, et al,. 2013. Faktor-Faktor yang Berpengaruh Terhadap Lamanya Perawatan pada Pasien Pasca Operasi Laparatomi di Instalasi Rawat Inap Brsu Tabanan. Jurnal Fakultas Kedokteran, Universitas Udayana, Indonesia.

[3] Mazzocca, Augustus D., et al. 2007. Tendon and bone responses to a collagen-coated suture material. J Shoulder Elbow Surg. Sep-Oct;16(5 Suppl):S222-30. Epub 2007 Apr 19.

[4] Almubarak, Luluah. 2013. Cutaneous Wound Closure Materials : An Overview and Update. J Cutan Aesthet Surg. 2013 Oct-Dec; 6(4): 178-188.

[5] Lee, Hye Sun, et al. 2013. Antimicrobial and biodegradable PLGA medical sutures with natural grapefruit seed extracts. Materials Letters 95 (2013) 40-43

[6] K. S. Silvipriya, K. Krishna Kumar, A. R. Bhat, B. Dinesh Kumar, Anish John, Panayappan lakshmanan, 2015. Collagen: Animal Sources and Biomedical Application Journal of Applied Pharmaceutical Science Vol. 5 (03), pp. 123-127, March, 2015

[7] Ehsan Oskoueian, Norhani Abdullah, Syahida Ahmad, Wan Zuhainis Saad 1, Abdul Rahman Omar, Yin Wan Ho, 2011. Bioactive Compounds and Biological Activities of Jatropha curcas L. Kernel Meal ExtractInt. J. Mol. Sci. 2011, 12, 5955-5970

[8] Izuogu, N.B., et al., 2013. The Potency of Moringa oleifera and Jatropha curcas Leaf extracts as Control for Root - Knot Nematode in Maize (Zea mays). International Journal of Phytofuels and Allied Sciences, September 2013, 2(1), 116-124 
[9] Thermo Nicolet. 2002.Introduction to Fourier Transform Infrared Spectrometry. Thermo Nicolet Corporation All rights reserver, Worldwide, www.thermonicolet.com

[10] Gallagher, A.J et al. 2012. Dynamic Tensile Properties of Human Skin. IRCOBI Conference

[11] Spielmann H, et. al. 2007. The practical application of three validated in vitro embryotoxicity tests. ATLA, 527-538.

[12] Mutia, Theresia et al. 2011. Alginates Membrane As Primary Wound Dressing And Topical Drug Delivery System For Infected Wound. Jurnal Riset Industri Vol. V, No.2, 2011, Hal 161 $-174$

[13] Wittaya, Thawien. 2013. Influence of Type and Concentration of Plasticizers on the Properties of Edible Film from Mung Bean Proteins. KMITL Science and Technology Journal Vol 13, no.1.

[14] Ukunowo, Wahab O, et al. 2013. Essential Oil of Grape Fruit (Citrus paradisi) Peels and Its Antimicrobial Activities. American Journal of Plant Sciences, 2013, 4, 1-9

[15] Namuli, Aidah, et al., 2014. Membrane Active Antibacterial Compounds in Methanolic Extract of Jatropha curcas and their Mode of Action against Staphylococcus aureus S1434 Escherichia coli E216. INTERNATIONAL JOURNAL OF AGRICULTURE \& BIOLOGY ISSN Print: 1560-8530; ISSN Online: 1814-9596

[16] Polleto, Matheus, et al. 2014. Native Cellulose: Structure, Characterization and Thermal Properties. Materials 2014, 7(9), 6105-6119 